\title{
Research on Green-credit Policy of Commercial Bank Based on Evolutionary Game Theory and DID Model
}

\author{
Xiong Zhong ${ }^{12, \text { a }}$ Dilong $\mathrm{Xu}^{12}$ Zhiyan Chen ${ }^{3}$ \\ ${ }^{1}$ Financial Research Institute of Guangzhou University, Guangzhou，GuangDong 510000, PR \\ China \\ ${ }^{2}$ Guangzhou International Institute of Finance, Guangzhou, GuangDong 510000, PR China \\ ${ }^{3}$ School of Economics and Statistics Institute, Guangzhou University ,Guangzhou, GuangDong \\ 510000, PR China \\ azhongxiong1218@hotmail.com
}

Key Words: commercial bank; green-credit policy; evolutionary game theory; double-difference model; bank performance

\begin{abstract}
. green-credit policy is one of the important channels for the conversation and development of environmental protection, it is also the main direction for Chinese commercial bank to implement reform and development, which arises high attention from all sectors of community. This paper is based on evolutionary game theory to discuss the factors of affecting green-credit policy implemented by commercial bank. It uses DID model to implement demonstration data analysis, learn its effect on performance of commercial bank. Results indicate that increasing green-credit policy revenue, reducing cost, strengthening the punishment cost without implementing green-credit policy can effectively promote the initiative of commercial bank to implement green-credit policy. Although the current effect is not so obvious, green-credit policy of commercial bank will bring plenty of advantages with the policy improvement and time progress, we should continually implement green-credit policy.
\end{abstract}

\section{Introduction}

In order to cope with the increasingly serious environment problems, China puts forward the resources-conservation and environment-friendly green development road. Under the background like this, developing green-credit policy has become to be one indispensable economic measure in the green development road, meanwhile, bank industry reformation and innovation mainly focuses on green-credit policy becomes to be one important topic. In order to further promote the initiative of commercial bank issuing green credit and its progress in China, under the environment economy and environment-finance theory instruction, this paper uses game theory and DID model to analyze relations between green credit and bank performance, it provides decision and references for the problems and defects in research and time of green-credit policy in China, improving green-credit policy system and accelerate the effective implementation of green-credit policy of Chinese commercial bank.

\section{Construction and discussion on evolutionary game theory model}

Green-credit policy is one kind of sustainable development idea, so it is necessary to establish dynamic evolution model for bank to implement green-credit mechanism, introduce into evolutionary game theory and construct model research in the implementation process

\section{Green-credit evolutionary model among banks}

1. Participation subject and strategy assemble

There is profit competition whether to implement green credit or nor among banks, it regards both of them as participation subject, which means bank A and bank B all have 2 kinds of strategies whether to implement green credit or not, both make decision at the same time, there is no distinction in sequence. 
2. Establish parallel game pay-off matrix

Table 1 Diagrammatic sketch of parallel game pay-off matrix on green credit among banks

\begin{tabular}{|c|c|c|}
\hline $\begin{array}{l}\text { Bank A } \\
\text { Bank B }\end{array}$ & implement green credit & $\begin{array}{c}\text { Do not implement green } \\
\text { credit }\end{array}$ \\
\hline Implement & $(\mathrm{R}+\mathrm{S}, \mathrm{R}+\mathrm{S})$ & $(\mathrm{R}+2 \mathrm{~S}-\mathrm{M}, \mathrm{R}+\mathrm{M}-2 \mathrm{~F})$ \\
\hline Do not implement & $(\mathrm{R}+\mathrm{M}-2 \mathrm{~F}, \mathrm{R}+2 \mathrm{~S}-\mathrm{M})$ & $(\mathrm{R}-\mathrm{F}, \mathrm{R}-\mathrm{F})$ \\
\hline
\end{tabular}

In the above table, $\mathrm{R}>0$ means the management profit of bank gets from current customers, $\mathrm{S}$ $>0$ means the profit of bank in implementing green credit, such as credibility enhancement etc; $M$ $>0$ indicates that profit due to customer loss by implementing green credit; $F>0$ means the punishment cost due to regulation violation by bank, including penalty, business suspension etc.

3. Evolutionary game process

Suppose the percentage of bank implementing green credit is $\mathrm{P}$, and the percentage of banks do not implement green credit is 1-P, it adopts 2 kinds of expectation profit of strategy game, and they are respectively $\mathrm{u}_{1}$ and $\mathrm{u}_{2}$. The average profit of bank group is $\mathrm{u}$, and it has the following equation:

$\mathrm{u}_{1}=\mathrm{p}(R+S)+(1-\mathrm{p})(R+2 S-M)=R+S+(1-\mathrm{p})(S-M)$

$\mathrm{u}_{2}=\mathrm{p}(R+M-2 F)+(1-\mathrm{p})(R-F)=R-F+\mathrm{p}(M-F)$

$\mathrm{u}=\mathrm{pu}_{1}+(1-\mathrm{p}) \mathrm{u}_{2}$

It gets the copy equation according to the above equation:

$F(\mathrm{p})=\mathrm{dp} / \mathrm{dt}=\mathrm{p}\left(\mathrm{u}_{1}-\mathrm{u}\right)=\mathrm{p}(1-\mathrm{p}) \quad\left(\mathrm{u}_{1}-\mathrm{u}_{2}\right)$

$=\mathrm{p}(1-\mathrm{p})[2 S+F-M-\mathrm{p}(S-F)]$

Through further analysis on stable state of copy dynamic equation, ESS meets the equilibrium point $F^{\prime}\left(\mathrm{p}^{*}\right)<0$. Suppose $\mathrm{p}^{*}=0, \quad \mathrm{p}^{*}=1, \quad \mathrm{p}^{*}=(2 S+F-M) /(S-F)$, and $0<(2 \mathrm{~S}+\mathrm{F}-\mathrm{M}) /(\mathrm{S}-\mathrm{F})$ $<1$, we learn that when $\mathrm{p}^{*}=(2 S+F-M) /(S-F)$, ESS is the real stable state and forms hawk dove game curve. This means when competition profit of bank meets the above assumption, in the evolutionary process of long time, implementation of green credit will be finally stabilized at ( $2 \mathrm{~S}+\mathrm{F}-\mathrm{M}) /(\mathrm{S}-\mathrm{F})$ or so, which is indicated by figure 1 .
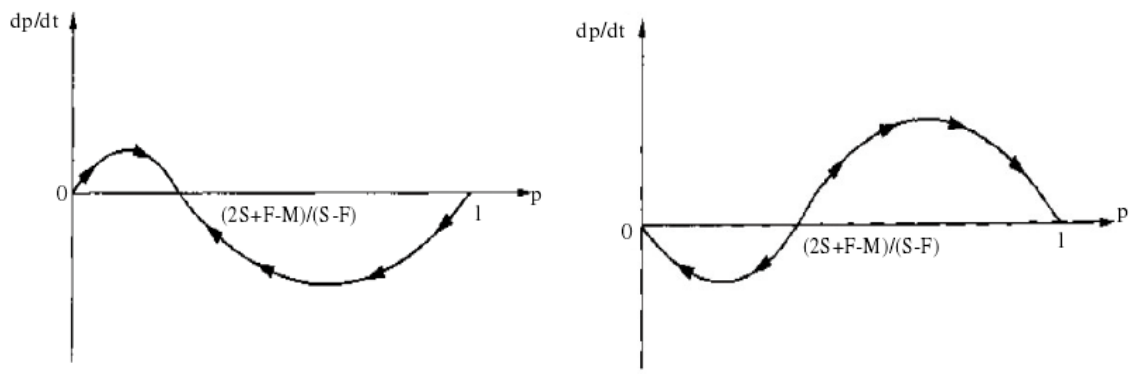

Figure 1 Phase diagram of hawk-dove game copy dynamic equation

Figure 2 Phase diagram of coordinated game copy dynamic equation

While when $(2 \mathrm{~S}+\mathrm{F}-\mathrm{M}) /(\mathrm{S}-\mathrm{F})<0, \mathrm{~S}-\mathrm{F}<0, \mathrm{~S}-\mathrm{F}<2 \mathrm{~S}+\mathrm{F}-\mathrm{M}, \quad F^{\prime}(0)<0, \quad F^{\prime}(1)<0$, $F^{\prime}[(2 S+F-M) /(S-F)]>0$, which means $\mathrm{p}^{*}=0$ and $\mathrm{p}^{*}=1$ is the purification stable strategy of this game, $\mathrm{p}^{*}=(2 S+F-M) /(S-F)$ forms coordinated game, its copy dynamic phase diagram tends to form stable state $\mathrm{p}^{*}=0$, then all banks do not implement green credit. While when it tends to be $\mathrm{p}^{*}=1$, which means all banks will implement green credit, the details please see figure 2:

Through the above evolutionary model we can see that green credit should strengthen intervention of supervision department to make violation inspection and punishment, only this can it accelerate more banks to choose implementing green credit. Meanwhile, it should unify standard and strictly supervise in the early supervision period, only this can it effectively control the violation rate of banks, this can also properly increase the violation cost of banks so as to enlarge 
implementation range of green credit.

\section{Evolutionary model of green credit between local government and commercial bank}

Participation person is local government and commercial bank, the action assemble of local government equals to supervision or no supervision, the action assemble of commercial bank equals to loan or no loan(green credit), action space and action sequence is the common knowledge. GC1 means the supervision cost of local government on pollution enterprise, GR1 is the profit of local government implementing low-carbon economy, GC2 is the reduced cost of bank implementing green credit, $\mathrm{T}$ is the tax revenue obtained from pollution enterprise by local government, BR1 is the loan profit on pollution enterprise by bank, BR2 is the additional profit of bank implementing green credit, BC1 is the bad debt loss of commercial bank, BC2 is the loss due to customer loss by bank. In view of this, carbon game analysis between local government and commercial bank is as follows:

$($ supervision, loan $)=($ GR-GC1, - BC1 $), \quad($ no supervision, loan $)=(\mathrm{T}+\mathrm{GC1}, \mathrm{BR} 1)$, ( supervision, no loan $)=($ GR-GC1+GC2, BR2 $)$, (no supervision, no loan $)=($ GC1-GC2+T, BR2-BC2)

From the pure strategic Nash equilibrium, we should stand in the aspect of local government, commercial continues to make loan, government continues to make supervision, which will reduce tax revenue, and meanwhile increase supervision cost, so local government will choosing no supervision. While commercial bank implants green credit exclude enterprises, which indicates there is environment problems, government making supervision on enterprises will reduce supervision cost on commercial bank, but it will reduce tax revenue and government performance, so government will choose no supervision, therefore9supervision, no supervision) is the Nash equilibrium. From the analysis on mixed strategy Nash equilibrium, whether local government makes supervision or not relates to loan of commercial bank.

$$
U_{B}=-B C 1^{*} \mathrm{a}^{*} \mathrm{~b}+\mathrm{a}^{*}(1-\mathrm{b})^{*} B R 2+(1-\mathrm{a})^{*} \mathrm{~b}^{*} B R 1+(1-\mathrm{a})^{*}(1-\mathrm{b})^{*}(B R 2-B C 2) \quad \text { (5) }
$$

The first-order derivative is as follows: $\frac{\partial U_{B}}{\partial \mathrm{b}}=\mathrm{a}^{*}(B C 1+B C 2+B R 1)+B R 1-B R 2+B C 2=0$

$$
\mathrm{a}^{*}=\frac{B R 1-B R 2+B C 2}{B C 1+B C 2+B R 1}
$$

From the above equation, we can know that $\mathrm{c}^{*}$ depends on loan profit by commercial bank, bad asset loss and green credit etc, it has no relation to supervision cost, profit and tax revenue of local government, which means the more loan profit of commercial bank gets from prepaid enterprises, the bigger probability of local government in supervision, commercial bank will have bigger loss in loan inspection from low-carbon enterprise, the bigger risk, the low supervision probability of local government, then commercial bank will conscientiously implement green credit.

\section{Construction and discussion on double difference and DID model}

DID model is also called as double difference model or double difference method, it divides sample data into procession group and matched group, of which, procession group is the sample of implementation policy, matched group is the sample without implementing policy, then it calculates changes of one index(such as performance) of 2 groups before and after policy implementation, it gets 2 variables, finally it calculates $\mathrm{D}$-value of 2 variables(that is double difference value), it combines with horizontal comparison and vertical comparison and gets the following equation:

$$
\begin{aligned}
& \mathrm{d}_{I D}=\Delta \bar{Y}_{\text {treatment }}-\Delta \bar{Y}_{\text {control }} \\
& =\left(\bar{Y}_{\text {treatment, } \mathrm{t}_{1}}-\bar{Y}_{\text {treatment, } \mathrm{t}_{0}}\right)-\left(\bar{Y}_{\text {control, } \mathrm{t}_{1}}-\bar{Y}_{\text {control, } \mathrm{t}_{0}}\right)
\end{aligned}
$$


Of which, $\mathrm{d}$ is the estimation of double difference, $\mathrm{Y}$ is the explanation variable, procession group is indicated as treatment, matched group is indicated by control, before policy implementation is $t_{0}$, after policy implementation is $t_{1}$ 。

Here is uses 2 stages of implementing green credit in 2007 to distinguish whether policy is implemented or nor, it divides sample into 2 groups of publishing green credit data in details and publishing green credit data without details, which is the so-called procession and matched group, it makes research on effect of green credit on total asset profit rate of banks through changes before and after policy implementation.

Suppose y represents the total asset profit rate of bank, A and B are respectively publication group and no publication group, command $\mathrm{dA}$ as the dummy variable whether publishes green credit or not, one with publication is 1 , one without publication is $0, \mathrm{~T}$ indicates whether data is the dummy variable after policy implementation of green credit or not, when $\mathrm{T}=1$, it indicates Yes, $\mathrm{T}-0$ means no. The equation is as follows according to these data:

$$
\mathrm{y}_{\mathrm{it}}=\alpha_{0}+\alpha_{1} T_{\mathrm{it}}+\alpha_{2} \mathrm{~d} A_{\mathrm{it}}+\delta T_{\mathrm{it}} \times \mathrm{d} A_{\mathrm{it}}+\mu_{\mathrm{it}}
$$

Here $\mathrm{y}$ is the explained variable, cross term $\mathrm{dA} \times \mathrm{T}$ indicates observed value is not only publication group but also the dummy variable after policy implementation, and parameter $\delta$ is the observed policy result.

This paper makes research on bank performance, it uses ROA to reflect the finance performance of enterprise, total asset profit rate=pure profit/final total asset amount*100\%, which is used to as the important index of measuring the ability of enterprise using asset to obtain profit, the higher index means the stronger ability to get profit by enterprise. The selected sample data is the ROA of 16 listed enterprises from 2005 to 2012. On procession group and matched group, except for the original standard, it also increases several variable factors of affecting profit rate of bank asset, which is asset quality; it uses LLR and IL to indicate. Asset adequacy uses legal right and EA to indicate, management efficiency uses COST to indicate, the statistics of 2 groups of data description is indicated by the following table 2 :

Table 2 Descriptive statistics of procession group and matched group

\begin{tabular}{|c|c|c|c|c|c|c|c|c|c|c|}
\hline \multirow{2}{*}{ Index } & \multicolumn{4}{|c|}{ Procession group } & \multicolumn{6}{c|}{ Matched group } \\
\cline { 2 - 12 } & ROA & LLR & IL & EA & COST & ROA & LLR & IL & EA & COST \\
\hline sample & 80 & 80 & 80 & 80 & 80 & 48 & 48 & 48 & 48 & 48 \\
\hline average & 0.012 & 1.892 & 0.025 & 0.052 & 0.374 & 0.009 & 1.997 & 0.022 & 0.054 & 0.356 \\
\hline $\begin{array}{c}\text { Standar } \\
\text { d } \\
\text { differen } \\
\text { ce }\end{array}$ & 0.015 & 1.055 & 0.044 & 0.026 & 0.065 & 0.003 & 1.128 & 0.024 & 0.027 & 0.061 \\
\hline $\begin{array}{c}\text { maximu } \\
\text { m }\end{array}$ & 0.116 & 4.996 & 0.260 & 0.098 & 0.681 & 0.016 & 4.493 & 0.096 & 0,131 & 0.453 \\
\hline $\begin{array}{c}\text { minimu } \\
\text { m }\end{array}$ & 0.000 & 0,049 & 0.004 & -0.137 & 0.267 & 0.001 & 0.412 & 0.003 & -0.005 & 0.235 \\
\hline
\end{tabular}

It establishes fixed effect model by combining with the above-mentioned data, $\mathrm{a}_{\mathrm{i}}$ indicates the variable changes with individual relevant factors but without changing with time, which makes error term independent of grouping variable, the established model is as follows:

$$
\mathrm{y}_{\text {it }}=\alpha_{0}+\alpha_{1} T_{\text {it }}+\alpha_{2} \mathrm{~d} A_{\text {it }}+\delta T_{\text {it }} \times \mathrm{d} T_{\text {it }}+\alpha_{\mathrm{i}}+\mu_{\mathrm{it}}
$$

Through differential treatment it deletes $\mathrm{a}_{\mathrm{i}}$, meanwhile, it makes analysis on measurement of double difference estimation, and it has no effect and gets the following:

$$
\Delta \mathrm{y}_{\mathrm{i}\left(\mathrm{t}_{1}-\mathrm{t}_{0}\right)}=\alpha_{1} \Delta T_{\mathrm{it}}+\delta \Delta\left(T_{\mathrm{it}} \times \mathrm{d} A_{\mathrm{it}}\right)+\Delta \mu_{\mathrm{it}}
$$

It adopts the common least square method to make regression analysis; it can get the following result, which is indicated by the following table 3 : 
Table 3 Implementation effect and time trend of policy implementation: difference estimation

\begin{tabular}{|c|c|c|c|c|}
\hline & \multicolumn{3}{|c|}{ Dependent variable: profit rate of bank total asset } \\
\hline & 1 & 2 & 3 & 4 \\
\hline Policy publication & $-0.018^{*}$ & $-0.018^{*}$ & & \\
\hline $\begin{array}{c}\text { publication in the } \\
\text { year }\end{array}$ & & & -0.008 & \\
\hline $\begin{array}{c}\text { The first year of } \\
\text { policy publication }\end{array}$ & & & & $-0.018^{*}$ \\
\hline $\begin{array}{c}\text { The second year of } \\
\text { policy publication }\end{array}$ & & & & -0.018 \\
\hline $\begin{array}{c}\text { The third year of } \\
\text { policy publication }\end{array}$ & & & & -0.015 \\
\hline $\begin{array}{c}\text { The fourth year of } \\
\text { policy publication }\end{array}$ & & & & -0.015 \\
\hline $\begin{array}{c}\text { The fifth year of } \\
\text { policy publication }\end{array}$ & & 112 & 64 & -0.015 \\
\hline Sample capacity & 112 & 0.08 & 0.04 & 0.13 \\
\hline R & 0.09 & 1,94 & 0.52 & 1.04 \\
\hline F & 5.38 & & & \\
\hline
\end{tabular}

( Notes: here * means it is obvious under the $10 \%$ obvious level)

From the above-mentioned data, we can see the estimation result of model, which is the profit rate of green credit policy on total asset of bank is negative, there is difference in significance. Green-credit policy will reduce the profit and competition of bank to certain extent, while from the time trend, negative effect of policy on performance will gradually reduce.

By combining with the above evolutionary stable strategy analysis, this paper thinks that bank performance is very important for the implementation of green credit, but from the demonstration result of DID model, it thinks that green credit can not produce positive effect in bank performance, the cause is that China starts late in green-credit policy, it needs continual improvement, but it is very favorable for environment protection in the long run.

\section{Conclusion}

In a word, this paper makes research and analysis on green credit of commercial bank based on evolutionary stable strategy and DID model, learning that commercial bank is the subject of green credit, response and support on green credit largely depends on factors such as profit, cost, risk etc. It will greatly improve green credit initiative of commercial bank if we make improvement from these aspects. At present, the implementation effect of green-credit policy is not so obvious, it also has negative effect on bank performance, but with the policy improvement and time progress, it can finally help commercial bank to establish good image and credibility; enhance popularity and increase the loan willingness of enterprises, take active effect in environment protection.

\section{Acknowledgement}

This paper is supported by the Guangzhou Institute of international finance, "Guangzhou financial research project", "the research of green finance innovation and development", which focuses on Guangdong.

\section{References}

[1]Li Cheng, Bai Wei etc. How Green Credit Policy to be Effectively Implemented by Commercial Bank._- Research Based on Revolutionary Stable Strategy and DID Model [J].Nanfang Finance, 
[2]Long Weiyang, Ji Cailiu. Research on Green Policy Based on International Experience and Illumination on China [J]. Reform on Economic System, 2013 （3） : 155-158

[3]Zhang Saiying, Xiao Yangqing. Research on Chinese Commercial Bank to Impalement Game Model of Green Credit [Z].Knowledge Economy，2013（21）: 80-81

[4]Li Wang. Game Analysis on Green Credit [D]. Master Thesis of Capital Economics and Trade University, 2011

[5]Zhang Weiying Game Theory and Information Economics [M].Shanghai: Shanghai Triple Bookstore, 2006

[6]Mo Fan. Discussion on Improvement of Green Credit Mechanism in China from Perspective of Game Theory [J].Business Times，2011（23）: 83-84

[7]Jiang Xianling, Xu Helong, Yu Jin. Research on Commercial Bank to Support New Energy Industry Development_—_Take Beijing for Example [J].Modern Management Science, 2016 (2) : 15-17

[8]Wang Chaodi, Zhao Bin,Lv Suyue. Research on Green Credit Implementation Mechanism Based on Revolutionary Game [J]. Research on Finance Supervision， 2012（6） : 80-97

[9]Wang Xuan. Research on Green Credit Encouragement Mechanism of Commercial Bank [D]. Master Thesis of Anhui University of Finance and Economics, 2012 